\title{
DNA degradation in human teeth exposed to thermal stress
}

\author{
Diego Lozano-Peral(1, 1,2, , Leticia Rubio $11^{1,4}$, Ignacio Santos ${ }^{1}$, María Jesús Gaitán ${ }^{1}$, \\ Enrique Viguera $\mathbb{1}^{3}$ \& Stella Martín-de-las-Heras $\mathbb{(}^{1}$
}

Human identification from burned remains poses a challenge to forensic laboratories, and DNA profiling is widely used for this purpose. Our aim was to evaluate the effect of temperature on DNA degradation in human teeth. Thirty teeth were exposed to temperatures of 100,200 , or $400^{\circ} \mathrm{C}$ for $60 \mathrm{~min}$. DNA was quantified by Real-Time qPCR (Quantifiler Human DNA Quantification Kit) and fluorescence spectroscopy (Qubit 3.0 Fluorometer). DNA degradation was evaluated by using STR markers (AmpFLSTR Identifiler Plus PCR Amplification Kit) to determine the allele and locus dropout, inter-locus balance, and degradation slope (observed $(\mathrm{Oa})$ to expected $(\mathrm{Ea})$ locus peak height ratio against the molecular weight). Most of the genomic DNA was degraded between $100^{\circ} \mathrm{C}$ and $200^{\circ} \mathrm{C}$. At $100^{\circ} \mathrm{C}$, locus dropout ratios showed significant differences between the largest loci (FGA, D7S820, D18S51, D16S539, D2S1338 and CSF1PO) and amelogenin. Inter-locus balance values significantly differed between all dye channels except between NED and PET. The dropout ratio between D18S51 (NED) and amelogenin (PET) can be recommended for the evaluation of DNA degradation. The Oa/ Ea regression model can predict locus peak heights in DNA degradation $\left(R^{2}=0.7881\right)$. These findings may be useful to assess the reliability of DNA typing for human identification in teeth subjected to prolonged incineration.

Human identification from burned remains poses a challenge to forensic laboratories. It is required in a wide range of situations, including major disasters, terrorist attacks, and car accidents, among others ${ }^{1,2,3,4}$, and DNA typing is the usual approach. However, DNA is highly degraded in extremely charred bodies, hampering short tandem repeat (STR) analysis ${ }^{5}$.

Researchers have focused mainly on morphological, color and structural changes in bones and teeth heated at different temperatures (up to $1000^{\circ} \mathrm{C}$ ) rather than on the feasibility of nuclear DNA analysis $\mathrm{s}^{5,6,7,8,9,10}$. In cases of severe degradation, a full DNA profile is more readily obtained from hard (bone and teeth) than soft tissues ${ }^{2}$. Teeth are the hardest tissue in the human body, and their pulp is well protected by dentin, enamel, and cementum, explaining their frequent utilization to obtain DNA from compromised remains $s^{9,11,12}$.

The survival of dental DNA is highly dependent on the temperature and duration of the heat exposure ${ }^{13-15}$. It has generally been reported that dental DNA can withstand temperatures up to $400{ }^{\circ} \mathrm{C}$ for one hour but that its quantity and quality are superior after exposure to lower temperatures for shorter time periods (1-20 min), facilitating forensic identification ${ }^{9}$. Only a few studies have studied teeth exposed for more than $15 \mathrm{~min}$ at temperatures above $90^{\circ} \mathrm{C}^{16,17,18,19}$. Most researchers have reported that it is very difficult to extract DNA from teeth after their exposure to temperatures of $200-400{ }^{\circ} \mathrm{C}^{18,19,20}$, and no consensus has been reached on the degree of cremation at which teeth will still yield nuclear DNA signals ${ }^{7}$.

Real-Time PCR is the preferred technique for forensic samples because of its wide dynamic range and high sensitivity, although fluorescence assays can also be used for the rapid quantification of single-source samples ${ }^{9,21}$. However, successful forensic identification by genotyping requires DNA of adequate quantity and quality. There is a need for in-depth investigation to determine the degree of DNA degradation in teeth burned at different temperatures and time of exposures. The objective of this study was to quantify the DNA in teeth exposed for 60 min to temperatures of 100,200 , or $400{ }^{\circ} \mathrm{C}$ and evaluate its degradation by examining locus dropout, peak height dropout ratio, inter-locus balance, and degradation slope.

\footnotetext{
${ }^{1}$ Department of Forensic Dentistry and Medicine, Instituto de Investigación Biomédica de Málaga-IBIMA (CE-18), School of Medicine, University of Malaga, 29071 Malaga, Spain. ${ }^{2}$ Supercomputing and Bioinnovation Center, Servicios Centrales de Apoyo a la Investigación, University of Malaga, 29590 Malaga, Spain. ${ }^{3}$ Department of Cellular Biology, Genetics and Physiology, University of Malaga, 29071 Malaga, Spain. ${ }^{4}$ These authors contributed equally: Diego Lozano-Peral and Leticia Rubio. ${ }^{\varpi}$ email: lorubio@uma.es
} 


\section{Material and methods}

Samples. Forty healthy human teeth (molars and premolars) were obtained from adult patients (25 females and 15 males) aged between 19-74 years (mean of 42.7 years) at dental clinics in Malaga and Cadiz (Spain). All patients provided their written informed consent to participation in this study, which was approved by the Human Research Ethics Committee of the University of Malaga (CEUMA 2013-0048-H) and conducted in accordance with the Declaration of Helsinki and with national data protection legislation (Organic Law 3/2018).

All studied teeth were extracted for valid clinical reasons (periodontal disease or orthodontic treatment) and were free of cavities, endodontics, or reconstruction. After extraction, they were washed with distilled water, and their external surfaces were cleaned with curettes to remove any extraneous material. The teeth were then stored under controlled conditions of $21^{\circ} \mathrm{C}$ and $65 \%$ humidity until their dispatch to the laboratory. In order to remove the exogenous DNA from tooth surfaces ${ }^{22-26}$, teeth were immersed in $3 \%$ sodium hypochlorite solution for $1.5 \mathrm{~min}$ and rinsed with sterile water to remove any remaining bleach. Next, samples were irradiated with 256-nm UV light (Telstar Mini V/PCR. Telstar Industrial S.L., Terrassa, Spain) for $10 \mathrm{~min}$. Samples were then randomly divided into four groups of 10 teeth each.

Experimental conditions for furnace incineration. Previous studies reported that DNA profiling is difficult to obtain from teeth after their exposure to $400{ }^{\circ} \mathrm{C}^{9,27}$. The temperature of fire and time of exposure of corpses can vary in the different forensic scenarios. For example, a fire could be subjected to many different temperatures depending on the origin or contributing factors. Based on these studies, we have selected time and temperature of heat exposure to embrace multiple circumstances in a forensic context in the current research. One group of teeth $(n=10)$ was kept at room temperature and served as controls. The remaining groups were exposed to temperatures of 100,200 or $400{ }^{\circ} \mathrm{C}$ for $60 \mathrm{~min}$. Samples were individually placed in $99 \%$ alumina crucibles and heated in a muffle furnace (Nabertherm LT 40/12, Nabertherm GmbH, Germany) to the corresponding temperature at a heating rate of $10^{\circ} \mathrm{C} / \mathrm{min}$ and then maintained at this temperature for $60 \mathrm{~min}$ before being removed and left to cool at room temperature.

DNA extraction. Samples were pulverized in liquid nitrogen with a 6770 Freezer/Mill (SPEX SamplePrep, LLC, Metuchen, USA). Powder teeth $(0.5 \mathrm{~g})$ were demineralized and lysed in a buffer containing $500 \mu \mathrm{L}$ of $0.5 \mathrm{M}$ EDTA, $35 \mu \mathrm{L}$ SDS (10\%) and $100 \mu \mathrm{L}$ of proteinase $\mathrm{K}(20 \mathrm{mg} / \mathrm{mL})$. Following 24 -h incubation at $37^{\circ} \mathrm{C}$ with continuous agitation $(300 \mathrm{rpm})$, the tubes were centrifuged at $13,000 \mathrm{rpm}$ for $3 \mathrm{~min}$. The supernatants were transferred and mixed with $500 \mu \mathrm{L}$ of phenol:chloroform:isoamyl alcohol (25:24:1) and centrifuged again at 13,000 rpm for $3 \mathrm{~min}$. Then, the supernatants were taken and added to Centricon-100 concentrators (Centricon-100, Millipore, Bedford, MA) and centrifuged at $2500 \mathrm{rpm}$ for $20 \mathrm{~min}$. Finally, concentrators were placed into $1.5 \mathrm{~mL}$ microcentrifuge tubes and DNA was recovered in $30 \mu \mathrm{L}$ of the elution buffer $(10 \mathrm{mM}$ Tris/ $\mathrm{HCl}, \mathrm{pH}$ 8.5) after centrifugation at $2500 \mathrm{rpm}$ for $20 \mathrm{~min}$. Blanks were included in DNA extraction procedures and PCR amplifications. Samples were stored at $-20^{\circ} \mathrm{C}$ before DNA analysis.

DNA quantification. Two methods were applied to quantify the DNA in samples: The Quantifiler Human DNA Quantification Kit (Thermo Fisher, Foster City, California, USA), using an Applied Biosystems 7500 RealTime PCR system according to the manufacturer's protocol ${ }^{28}$; and the Qubit 3.0 Fluorometer (Life Technologies, Carlsbad, California, USA), following the manufacturer's instructions (Qubit dsDNA BR and Qubit dsDNA HS Assay Kits $)^{29,30}$.

DNA integrity. DNA integrity was examined by digital electrophoresis using a 2100 Bioanalyzer Instrument-Agilent (Agilent Technologies, Waldbronn, Germany) to visually confirm DNA degradation ${ }^{31}$. The size distribution of DNA molecules was visualized and analyzed using the Agilent High Sensitivity DNA Kit ${ }^{32}$.

DNA degradation analysis. STR genotyping was performed with an AmpFLSTR Identifiler Plus PCR Amplification Kit. PCRs were performed using the C1000 Touch Thermal Cycler (Bio-RAD) with the following conditions: $95^{\circ} \mathrm{C}$ for $11 \mathrm{~min}$ followed by 28 cycles of $94^{\circ} \mathrm{C}$ for $20 \mathrm{~s}$ and $59^{\circ} \mathrm{C}$ for $3 \mathrm{~min}$, and a final extension at $60^{\circ} \mathrm{C}$ for $10 \mathrm{~min}$. PCR products were kept at $4^{\circ} \mathrm{C}$ (Thermo Fisher) $)^{33}$. The amount of DNA template in all samples is shown in the Supplementary Dataset (Table S11). Amplification products were analyzed by capillary electrophoresis injection using an ABI PRISM 3130 Genetic Analyzer in accordance with the manufacturer's instructions. Samples were analyzed with GeneMapper Software v4.0 from Applied Biosystems, selecting a detection threshold of 50 relative fluorescence units (RFU) ${ }^{20}$. For heterozygous loci, the mean for the two alleles was calculated and used to correct for a possible imbalance between peaks. Peak heights of homozygous loci were also divided by two to normalize for diploidy ${ }^{34,35}$.

DNA degradation was studied by considering locus dropout, peak height dropout ratio, inter-locus balance, and degradation slope, as follows:

1. Locus dropout was determined as the percentage of amplified loci in each group of teeth. This value was compared with the sum of locus peak heights (in RFU) for each heat condition (Table S1).

2. Locus peak height dropout ratio was calculated as the percentage peak height dropout of the smallest locus to largest loci $\mathrm{i}^{23,35}$. In the control and $100^{\circ} \mathrm{C}$ groups, the smallest locus, amelogenin (106-112 bp), was compared with the six largest: FGA (196-348 bp), D7S820 (253-293 bp), D16S539 (248-296 bp), D18S51 (264-351), CSF1P0 (280-316 bp), and D2S1338 (291-359 bp) (Tables S2-S7, respectively). 


\begin{tabular}{|c|c|c|c|c|c|c|c|c|}
\hline \multirow[b]{2}{*}{ Teeth group } & \multicolumn{4}{|l|}{ Quantifiler } & \multicolumn{4}{|l|}{ Qubit } \\
\hline & $\begin{array}{l}\text { Average DNA } \\
\text { value }(\mathrm{ng} / \mu \mathrm{L})\end{array}$ & $\operatorname{Min}(\mathrm{ng} / \mu \mathrm{L})$ & $\operatorname{Max}(\mathrm{ng} / \mu \mathrm{L})$ & SEM & $\begin{array}{l}\text { Average DNA } \\
\text { value (ng/ } \mu \mathrm{L})\end{array}$ & $\operatorname{Min}(\mathrm{ng} / \mu \mathrm{L})$ & $\operatorname{Max}(n g / \mu L)$ & SEM \\
\hline Control & $133.95\left(^{\star}\right)$ & 65.34 & 226.96 & 19.13 & $101.76\left(^{*}\right)$ & 53.3 & 180 & 12.45 \\
\hline $100^{\circ} \mathrm{C}$ & 10.83 & 0.24 & 35.87 & 4.35 & 27.96 & 0 & 171 & 23.71 \\
\hline $200^{\circ} \mathrm{C}$ & $1.3 \times 10^{-2}$ & 0 & $4.3 \times 10^{-2}$ & $5.2 \times 10^{-3}$ & $3.4 \times 10^{-2}$ & 0 & 0.15 & $4.3 \times 10^{-2}$ \\
\hline $400^{\circ} \mathrm{C}$ & $1.0 \times 10^{-4}$ & 0 & $8,1 \times 10^{-4}$ & $2.6 \times 10^{-4}$ & 0 & 0 & 0 & - \\
\hline
\end{tabular}

Table 1. DNA concentration of control and incinerated group of teeth using Quantifiler and Qubit methods. ${ }^{*}$ Significant differences $(\mathrm{p}<0.01)$ between control group and all incinerated groups with Quantifiler and between control group and incinerated group at 100 and $200{ }^{\circ} \mathrm{C}$ with Qubit.

3. The inter-locus balance was calculated by comparing the deviations of the peak height for each locus from the sample mean. Signal values were normalized by dividing the difference by the square root of the mean peak height per locus ${ }^{36}$ (Table S8).

$$
\text { Interlocus balance }=\frac{\text { locus height }- \text { mean peak height from } 16 \text { loci }}{\sqrt{\text { mean peak height from } 16 \text { loci }}}
$$

The mean inter-locus balance (in arbitrary units) was analyzed by dye group (6-FAM, VIC, NED and PET, hereafter FAM, VIC, NED and PET, respectively) in the control and $100^{\circ} \mathrm{C}$ groups (Table S9).

4. The sum of peak heights for each locus was used to evaluate the degradation slope of DNA produced by the burning. Values for the $100{ }^{\circ} \mathrm{C}$ and control groups were considered as observed allelic peak (Oa) and expected allelic peak (Ea), respectively (Table S10). The Oa/Ea ratio was calculated for each locus ${ }^{37}$. After studying different regression models, the curve with the highest $\mathrm{R}^{2}$ value was selected.

Statistical analysis. R statistical software v.3.1.0 and RStudio version 1.1.442 (http://www.r-project.org) ${ }^{38}$ and Statgraphics Centurion 18 (Statgraphics Technologies, Inc., USA) were used for statistical analysis. Figure 3 and Figure S7 were created in $\mathrm{R}$ using the package ggplot $2^{38}$. Significance was assessed by one-way analysis of variance (ANOVA), considering $\mathrm{p}<0.05$ as statistically significant. When F-values were significant, the Tukey honestly significant difference (HSD) post-hoc test was applied for multiple comparisons.

\section{Results}

DNA quantification. Table 1 exhibits the mean, standard error of mean (SEM), minimum, and maximum DNA concentrations for the control and incinerated groups. DNA values obtained with Quantifiler and Qubit significantly differed between the control group and all incinerated groups $(\mathrm{p}<0.01)$ but not among the incinerated groups (Table 1).

Among the teeth incinerated at $100{ }^{\circ} \mathrm{C}$, DNA was detected in $100 \%$ of the samples using Quantifiler method and in $60 \%$ using Qubit. Among those incinerated at $200{ }^{\circ} \mathrm{C}$, DNA was detected in $80 \%$ with Quantifiler and in $30 \%$ with Qubit. In the group incinerated at $400{ }^{\circ} \mathrm{C}$, DNA was detected in $20 \%$ with Quantifiler and in $0 \%$ with Qubit.

The minimum DNA concentration detected with Quantifiler Human DNA Quantification Kit was 0.215 pg/ $\mu \mathrm{L}\left(400^{\circ} \mathrm{C}\right.$ group) and $0.053 \mathrm{ng} / \mu \mathrm{L}$ with Qubit $\left(20{ }^{\circ} \mathrm{C}\right.$ group). Quantifiler results were adopted for calculation of DNA template in STR PCR.

DNA integrity. DNA bands were generally larger in the control teeth than in those burned at $100{ }^{\circ} \mathrm{C}$ for 60 min (Figs. S1 and S2). In almost all control teeth, DNA bands were accumulated closer to the largest molecular weight marker $(10,380 \mathrm{bp})$ in comparison to the burned teeth (Fig. S1). DNA smearing was more evident in the teeth burned at $100{ }^{\circ} \mathrm{C}$ (Fig. S2). No DNA was detected by the Bioanalyzer Instrument in teeth incinerated at 200 or $400{ }^{\circ} \mathrm{C}$.

DNA degradation. Locus dropout and STR profiles. All STR markers were detected in all samples from the control group and the group incinerated at $100{ }^{\circ} \mathrm{C}$ (Fig. 1). The percentage of amplified loci was $9.38 \%$ at $200{ }^{\circ} \mathrm{C}$ and $4.38 \%$ at $400{ }^{\circ} \mathrm{C}$ (Table S1; Fig. 1). The sum of locus peak heights was $299,564.0 \mathrm{RFU}$ in the control group, $255,796.5 \mathrm{RFU}$ in the $100^{\circ} \mathrm{C}$ group (14.6\% reduction versus controls), 1809.5 in the $200^{\circ} \mathrm{C}$ group ( $99.4 \%$ reduction versus controls), and $273 \mathrm{RFU}$ in the $400^{\circ} \mathrm{C}$ group (99.9\% reduction versus controls).

Electropherograms analyzing the quality of DNA profiles showed an inverse correlation in peak height signals with increasing molecular weight of loci (degradation slope) at 100,200 , and $400^{\circ} \mathrm{C}$ (Figs. S3-S6). The recovery of larger loci is much less probable at 200 and $400^{\circ} \mathrm{C}$ (Table S1, Locus dropout by size).

Locus peak height dropout ratio. In control samples, mean peak height dropout ratios for the amelogenin locus relative to FGA, D7S820, D18S51, and CSF1PO were $16.71 \%, 29.15 \%, 6.75 \%$, and $10.76 \%$, respectively, whereas the results for amelogenin relative to D16S539 and D2S1338 showed negative dropout ratios $(-49.43 \%$ and $-3.76 \%$, respectively) due to the higher peak height for these loci than for amelogenin. At $100{ }^{\circ} \mathrm{C}$, mean peak height dropout ratios for amelogenin relative to FGA, D7S820, D16S539, D18S51, CSF1P0, and D2S1338 were 


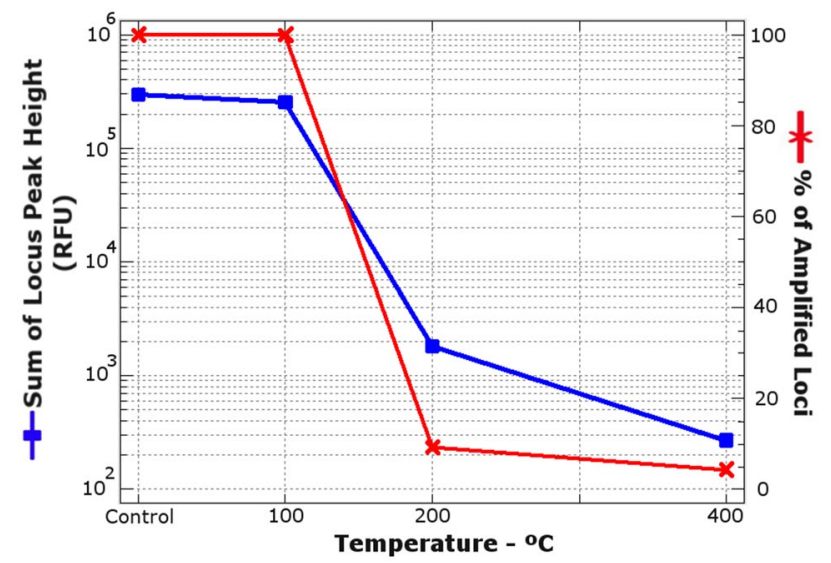

Figure 1. Effect of temperature on STR amplification. Sum of locus peak heights in relative fluorescence units (RFU) and percentage of amplified loci against temperature (without incineration-control, $21^{\circ} \mathrm{C}$ - and with incineration at 100,200 and $400{ }^{\circ} \mathrm{C}$ for $60 \mathrm{~min}$ ). Note that the sum of peak heights is represented to the power of 10 to improve the visualization of the figure.

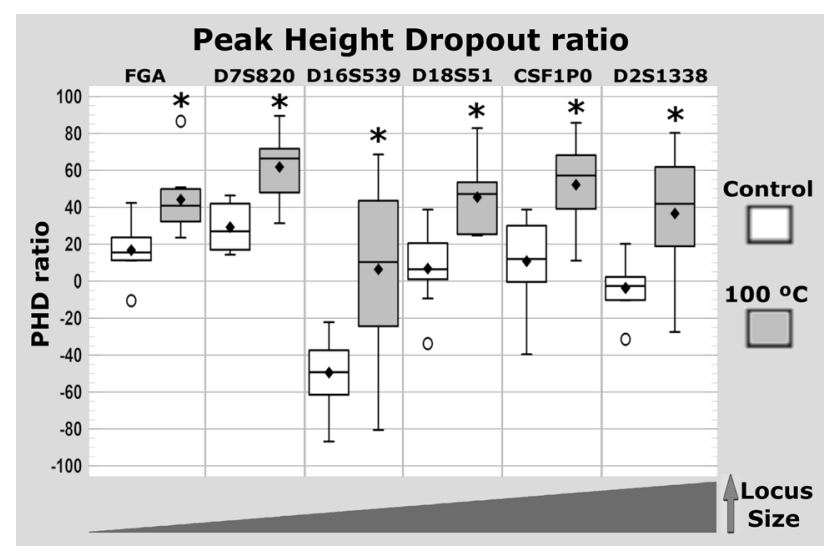

Figure 2. Box and whisker plot of locus peak height dropout (PHD) ratio in control and $100{ }^{\circ} \mathrm{C}$ groups. Dropout ratio was calculated as the percentage peak height dropout of the smallest locus (amelogenin) relative to the largest loci (FGA, D7S820, D16S539, D18S51, CSF1P0 and D2S1338). * Significant differences $(\mathrm{p}<0.01)$ between control group teeth and teeth incinerated at $100{ }^{\circ} \mathrm{C}$ for $60 \mathrm{~min}$.

$44.06 \%, 61.80 \%, 6.33 \%, 45.36 \%, 52.22 \%$, and 36.60\%, respectively (Tables S2-S7). Locus peak height dropout ratios significantly differed between the control group and the $100{ }^{\circ} \mathrm{C}$ group (sum of squared deviations $=3739$, 5330, 15,546, 7454, 8595, and 8147 for FGA, D7S820, D16S539, D18S51, CSF1P0, D2S1338, respectively; 1 degree of freedom; $\mathrm{p}<0.01$ ) (Fig. 2).

Locus peak height dropout ratio, inter-locus balance, and degradation slope (regression model) analysis were carried out between control samples and those exposed to $100^{\circ} \mathrm{C}$, as a low number of loci were amplified from samples exposed to 200 and $400{ }^{\circ} \mathrm{C}$. In fact, 3 and 12 loci were detected in two samples of the $200{ }^{\circ} \mathrm{C}$ group, and 7 loci in one sample of the $400^{\circ} \mathrm{C}$ group (Table S2).

Inter-locus balance by locus and dye color. Inter-locus balance values close to zero indicate a well-balanced profile, while negative and positive values indicate that the locus has peak heights below or above the mean, respectively (Fig. S7). Figure 3 shows inter-locus balance values for the control and $100^{\circ} \mathrm{C}$ groups by dye group. Greater general dispersion of inter-locus values was observed in the $100^{\circ} \mathrm{C}$ group than in controls. In the control group, significant differences were found between FAM and NED groups and between the VIC group and the remaining dye groups $(\mathrm{p}<0.01)$. In the $100{ }^{\circ} \mathrm{C}$ group, significant differences were found between all dye groups $(\mathrm{p}<0.01$ or $\mathrm{p}<0.05)$, except between NED and PET.

Degradation slope. Figure 4 plots the Oa/Ea ratio for each locus against the molecular weight in base pairs for the control and $100{ }^{\circ} \mathrm{C}$ groups. The "Y-logarithmic $\mathrm{X}$-square root" gave the best $\mathrm{R}^{2}$ value $(0.7881)$. The equation derived from the simple regression model is shown. Intermediate-small molecular weight locus (D5S818, vWA and $\mathrm{TH} 01$ ) had $\mathrm{Oa} / \mathrm{Ea}$ ratios close to 1. The highest $\mathrm{Oa} / \mathrm{Ea}$ ratio was for the amelogenin locus (1.23) (Fig. 4). 


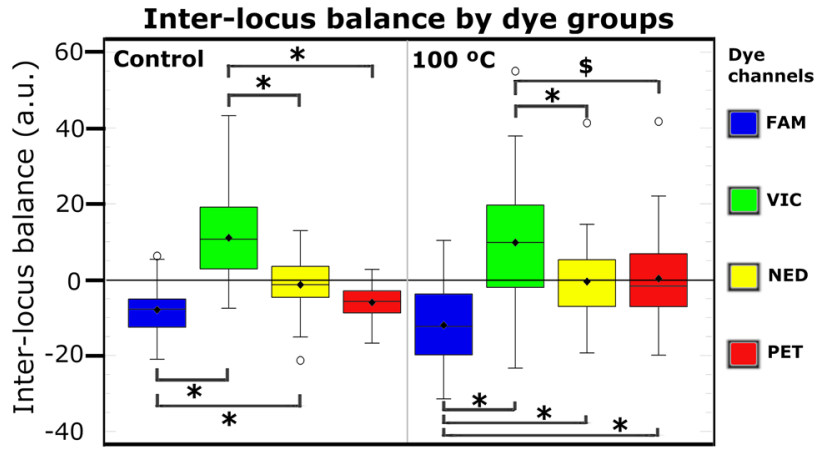

Figure 3. Inter-locus balance in arbitrary units (a.u.) is depicted by dye group (FAM, VIC, NED and PET) and temperature (control $-21^{\circ} \mathrm{C}$ and $100^{\circ} \mathrm{C}$ ). Significant differences: ${ }^{\star} \mathrm{p}<0.01,{ }^{\$} \mathrm{p}<0.05$ (Created using R Core Team, 2013 with package ggplot2 $)^{38}$.

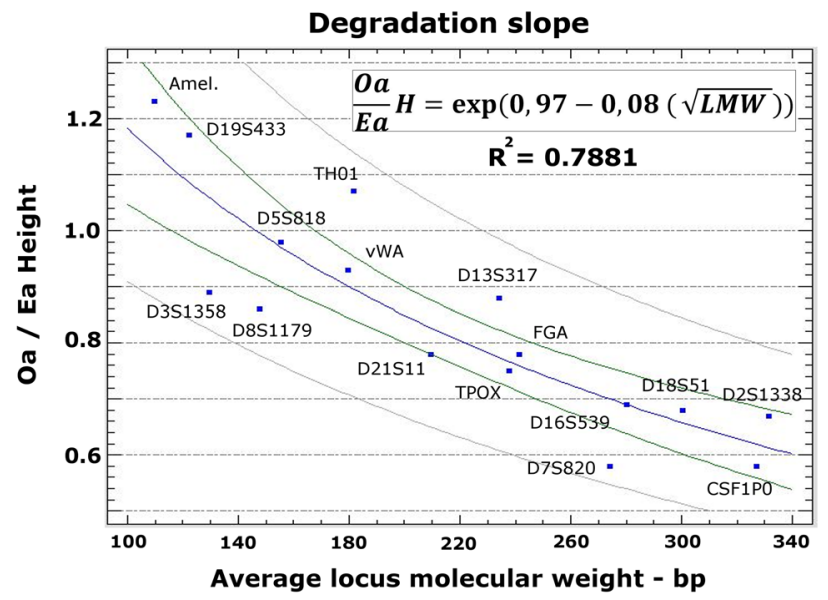

Figure 4. Degradation slope caused by temperature effect. Oa/Ea ratio for each locus is plotted against the molecular weight in base pairs for the control and $100^{\circ} \mathrm{C}$ groups. Simple regression model of "Y-Logarithmic $\mathrm{X}$-Square root" is represented by blue curve. Green and grey lines represent the confidence (95\%) and prediction limits of the model, respectively. The equation derived from this model is shown $(\mathrm{Oa} / \mathrm{Ea} \mathrm{H} \mathrm{Oa/Ea} \mathrm{height} \mathrm{ratio,}$ $L M W$ locus molecular weight in base pairs).

\section{Discussion}

DNA detection and integrity. Real-Time PCR methods (qPCR) have been developed for the accurate measurement of DNA quantity ${ }^{39}$, and a fluorescence spectroscopy technique (Qubit 3.0 Fluorometer) is also available for utilization in forensic samples ${ }^{9}$. In this study, we have exposed the teeth up to $400{ }^{\circ} \mathrm{C}$ as previous studies have reported that DNA profiling is difficult to obtain from teeth after that temperature of exposure ${ }^{9,27,40}$.

A decrease in the amount of DNA was observed from unheated control teeth to those heated at 100, 200, and $400{ }^{\circ} \mathrm{C}$ for $60 \mathrm{~min}$. In previous studies, it has been observed that tooth DNA concentration is not influenced by age or sex ${ }^{35,41}$. Application of qPCR and Qubit quantitative methods showed significant differences in the amount of DNA between control and incinerated teeth in line with previous findings ${ }^{42,43}$ but not among the incinerated groups, although these showed a wide dispersion of values, especially with Qubit. Both quantification methods revealed a major reduction in DNA concentration after exposure to $100{ }^{\circ} \mathrm{C}$ for $60 \mathrm{~min}$ (Table 1).

Although DNA measurements have been reported to vary among different quantification methods ${ }^{44}$, we found no significant difference in mean concentrations between Quantifiler and Qubit in the control or $100{ }^{\circ} \mathrm{C}$ groups. However, DNA was detected in all teeth exposed to $100^{\circ} \mathrm{C}$ with Quantifiler and in only $60 \%$ of these with Qubit. DNA was also more frequently detected in samples exposed to 200 or $400^{\circ} \mathrm{C}$ with the Quantifiler Human DNA Quantification Kit than with the Qubit method. The LOD of the Quantifiler Human DNA Quantification Kit is $<23 \mathrm{pg} / \mu \mathrm{L}$ ( $<13$ target copies) according to the manufacturer, although LODs of 6 pg per reaction ${ }^{45}$ and $<5 \mathrm{pg} /$ $\mu \mathrm{L}$ of $\mathrm{DNA}^{39}$ have also been described. In our study, the minimum DNA concentration detected with Quantifiler was $0.215 \mathrm{pg} / \mu \mathrm{L}$. At this range, stochastic or statistical effects of low copy locus sampling may produce significant variability in assay results, and they may explain the unexpected allele typing after exposure to $400{ }^{\circ} \mathrm{C}$ of incineration, which has previously been observed ${ }^{39}$. According to the present results, a minimum Quantifiler Human DNA Quantification-measured DNA concentration of $0.24 \mathrm{ng} / \mu \mathrm{L}$ may allow full STR typing (100\% 
amplification of expected locus) and a minimum Quantifiler Human DNA Quantification-measured DNA concentration of between $0.2 \mathrm{ng} / \mu \mathrm{L}$ and $0.2 \mathrm{pg} / \mu \mathrm{L}$ may allow a partial STR profile to be obtained. Regarding to Qubit quantitation, although the minimum DNA concentration detected in our study was $0.053 \mathrm{ng} / \mu \mathrm{L}$, the minimum Qubit-measured DNA concentration was $0.15 \mathrm{ng} / \mu \mathrm{L}$ for a partial STR profile and $4.8 \mathrm{ng} / \mu \mathrm{L}$ for a complete STR profile. Surprisingly, full or partial STR typing was obtained in several samples in which DNA was not detected with Qubit. The Quantifiler Human DNA Quantification Kit yielded more reliable and accurate results and an improved sensitivity for highly degraded samples in comparison to Qubit.

Visualization of DNA fragments up to $10 \mathrm{~kb}$ on Agilent 2100 Bioanalyzer Instrument provided visual confirmation of DNA degradation. Smear of DNA in electrophoresis results from DNA fragmentation due to degradation. In the present study, smear of DNA was more evident in teeth exposed to thermal stress than in controls because of the greater fragmentation of molecular DNA, as reported in a previous study ${ }^{46}$.

Temperature effect on locus dropout and STR profiles. According to the present findings, human genetic identification is possible from teeth incinerated at $100{ }^{\circ} \mathrm{C}$ for up to $60 \mathrm{~min}$ but almost impossible from teeth exposed to temperatures of $200^{\circ} \mathrm{C}$ and above. The highest locus dropout was observed in samples exposed to $200^{\circ} \mathrm{C}$ and $400^{\circ} \mathrm{C}$ (Fig. 1), and amelogenin Y alleles were also missing in two amplified male samples exposed to these temperatures. When DNA amounts are small, there is an increase in heterozygote peak height imbalance and in the number of undetected loci at 200 and $400{ }^{\circ} \mathrm{C}$ (Figs. S5, S6), mainly due to stochastic effects in pre-PCR sampling ${ }^{47}$. However, the undetected amelogenin $\mathrm{Y}$ allele at $400{ }^{\circ} \mathrm{C}$ may also result from the presence of a technology-related artefact peak overlapping the Y signal known as a dye blob (Fig. S6), described in detail elsewhere ${ }^{48}$.

The heat exposure on the DNA molecules produces the deamination of cytosine that is directly related to the increase of the temperature and the duration of the exposure ${ }^{49,50}$, generating a mutated daughter strand. This is an important issue in methods where DNA sequence is necessary, such as mtDNA typing by Sanger-type sequencing or STRs by DNA Next Generation Sequencing ${ }^{51}$. Because deamination of cytosine may result in inhibition of PCR or mutagenic DNA products, this is an important issue in methods where DNA sequence is crucial. In methods that rely on the amplicon length rather than the exact sequence (i.e. short tandem repeats used in human identification), deamination of cytosine may also originate a possible change of the nucleotide sequence and, if the impact is deeper, the loss of STR markers starting from the high molecular weight ones. Thermal degradation of DNA breaks covalent bonds within each DNA strand, leading to DNA fragmentation ${ }^{52}$. This study ${ }^{52}$ found that plasmid DNA degradation started after $5 \mathrm{~min}$ at $130^{\circ} \mathrm{C}$ and was complete at around $190^{\circ} \mathrm{C}$. STR profiling is dependent on the temperature and the duration of exposure, due to DNA fragmentation. Most studies have exposed teeth for short time periods of 2-15 min and have obtained fully amplified loci up to temperatures of $300{ }^{\circ} \mathrm{C}^{9,12,20}$, while STR typing was found to be reliable up to $16 \mathrm{~h}$ of exposure when the temperature was $90^{\circ} \mathrm{C}^{17}$. The present teeth were exposed for $60 \mathrm{~min}$, and loci were fully amplified up to $100^{\circ} \mathrm{C}$, whereas only partial STR profiles could be obtained at $200{ }^{\circ} \mathrm{C}$ and $400{ }^{\circ} \mathrm{C}$. The lesser degradation observed in teeth may be explained by the hardness of the surrounding tissue, which acts as a DNA protector ${ }^{9,11,22}$.

Locus peak height dropout ratio. The locus peak height dropout ratio has previously been studied in teeth stored for long time periods ${ }^{22,35}$. In the present study, all samples were subjected to the same storage conditions and DNA extraction procedure; therefore, the locus peak height dropout ratio results should not be influenced by differences in treatment between control and test teeth, as in previous studies ${ }^{37}$.

Statistically significant peak height dropout was observed in the six largest loci after exposure to $100{ }^{\circ} \mathrm{C}$ for $60 \mathrm{~min}$. The most affected amplicons were D7S820 and CSF1P0, with dropout ratios of $61.80 \%$ and $52.22 \%$, respectively, while the least affected were D16S539 and D2S1338 (Fig. 2). The lowest molecular weight corresponds to the FGA locus, followed by D7S820, D16S539, D18S51, CSF1P0, and D2S1338. Although we cannot rule out a low template amplification or inhibition effect, the lack of a precise correlation between locus peak height dropout rate and locus size may have two main explanations. First, primers specific to the DNA target may vary among loci, leading to the over- or under-amplification of some PCR products in comparison to others $^{53}$. Second, loci in the AmpFLSTR Identifiler Plus PCR Amplification Kit are tagged with different dyes (blue, green, yellow, and red channels for FAM, VIC, NED, and PET, respectively), and some channels can show different peak heights or signal intensities ${ }^{54,55}$. Given its possible effects on the peak height of each locus and therefore on the locus peak height dropout ratio in pairwise comparisons, the inter-locus balance was studied by locus and dye color.

Inter-locus balance analysis by loci and dye color. Mattayad et al. ${ }^{54}$ found that the inter-locus balance by dye color and locus was superior with the AmpFLSTR Identifiler Plus PCR Amplification Kit versus Investigator IDplex Plus Kit (QIAGEN, Hilden, Germany). In the present study, blue (FAM) and green (VIC) channels had higher locus peak heights with the AmpFLSTR Identifiler Plus PCR Amplification Kit. Debernardi et al. ${ }^{55}$ reported evidence of some differences in sensitivity of the blue channel between two ABI 3130xl Genetic Analyzers. Other kits currently in the market have integrated quality sensors and may be useful in future research. Various issues should be considered when using locus peak height dropout ratios to study DNA degradation. First, dropout ratios from loci with similar molecular weight but tagged with different dyes are not comparable if they differ in inter-locus balance. Second, differences in inter-locus balance values between kits mean that a variation in peak height dropout ratio can even be observed in the same locus tagged with the same dye. Third, inter-laboratory studies using the same kit must consider dye channel sensitivities to avoid possible differences in genetic analyzers, spectral calibrations, and/or dye matrix procedures between laboratories. Inter-laboratory and inter-instrument validation are crucial for comparable and reliable results. In the present study, inter-locus 
balance values were worse for VIC and FAM markers and better for NED and PET markers, which showed more similar values between them (Fig. 3). Although D2S1338 (VIC) was the largest locus, its peak height dropout ratio was the second lowest (36.6\%), while D7S820 (FAM), the second smallest locus, had the highest peak height dropout ratio (61.8\%). The fact that inter-locus balance values were highest for VIC and lowest for FAM may explain these results. In contrast, a better inter-locus balance was observed for loci tagged with NED and PET dyes under both control and heated conditions. Our results confirm that the dye color can influence the signal peak height; therefore, not only the locus molecular weight but also the fluorescent dye of each locus should be taken into account in DNA degradation studies. According to the locus dropout ratio and inter-locus balance results, the comparison between amelogenin (PET dye) and D18S51 (NED dye), the third largest locus, with a $45.36 \%$ dropout ratio, can be recommended for investigations of DNA degradation.

Degradation slope and expected peak heights. The degradation or "ski" slope describes the downward trend of a DNA electropherogram with increasing molecular weight ${ }^{37}$, which is attributed to DNA degradation and even observed in pristine DNA ${ }^{37}$. Differences in the PCR efficiency for each locus may lead to different loci signal intensities ${ }^{55}$. In addition, according to the present and previous findings ${ }^{54,55}$, locus peak height signals can also vary among marker dyes.

A reduction in $\mathrm{Oa} / \mathrm{Ea}$ values is observed with increasing molecular weight, which can be considered as DNA degradation from exposure to $100^{\circ} \mathrm{C}$ (Fig. 4). Oa/Ea rates were $<1$ in loci with molecular weight $>200 \mathrm{bp}$, demonstrating that the locus peak height dropout due to temperature is greater in these loci. Interestingly, $\mathrm{Oa} /$ Ea values were $>1$ for the two smallest loci, attributable to the amount of available template DNA and a greater PCR efficiency ${ }^{55}$. DNA is more fragmented after heat exposure, and it is more difficult to amplify loci with higher molecular weight, reducing the RFU signal detected. In contrast, the amplification of loci with lower molecular weight is less affected by DNA degradation. Consequently, there is a greater formation of primer/template complexes (binary complexes) with a larger amount of small amplicon DNA. In addition, there is a greater availability of free polymerase not bound to DNA for these binary complexes (ternary complexes formation), due to the lesser formation of binary complexes for amplicon loci of higher molecular weight. Hence, PCR efficiency may be higher for smaller loci in samples incinerated at $100^{\circ} \mathrm{C}$, and the RFU signal tended to be higher than in control samples. Loci with molecular weight between 150-200 bp showed intermediate Oa/Ea values of around 1. Therefore, the most consistent results were obtained for loci with a molecular weight $<200 \mathrm{bp}$. The Oa/Ea regression model obtained with the AmpFLSTR Identifiler Plus PCR Amplification Kit may estimate locus peak heights as a function of molecular weight in DNA degradation in teeth incinerated at $100^{\circ} \mathrm{C}$ for up to $60 \mathrm{~min}$.

Study limitations include its development in a controlled laboratory environment. It did not take into account the influence of the accelerant type or fire extinction method, among other relevant factors, including the duration of exposure. Furthermore, it was conducted in teeth lacking the protection provided by alveolar bone or maxillary bone. In addition, there was no exploration of the protective effect of facial tissues against external insults like high temperatures. Further research is needed to embrace other forensic scenarios with different exposure times and temperatures.

\section{Conclusion}

After 60 min of incineration, all STR loci were detected in all teeth exposed to $100{ }^{\circ} \mathrm{C}$, but genetic identification was almost impossible from teeth exposed to temperatures of $200{ }^{\circ} \mathrm{C}$ and above. STR amplification of DNA samples is time-consuming and can be costly, so determination of the minimum amount of DNA needed for full or partial STR typing may be of value for forensic laboratories. A statistically significant difference in the peak height dropout ratio of amelogenin relative to FGA, D7S820, D16S539, D18S51, CSF1P0, and D2S1338 was observed between unheated teeth and teeth exposed to $100^{\circ} \mathrm{C}$. NED and PET had a better inter-locus balance at $100{ }^{\circ} \mathrm{C}$ than the other dyes, and our locus peak height dropout ratio findings lead us to recommend the comparison of D18S51 (NED) with amelogenin (PET) in studies of DNA degradation. In addition, the slope ratio $(\mathrm{Oa} / \mathrm{Ea})$ obtained with the AmpFLSTR Identifiler Plus PCR Amplification Kit may estimate locus peak heights as a function of molecular weight for evaluating DNA degradation at up to $60 \mathrm{~min}$ of exposure to $100{ }^{\circ} \mathrm{C}$. This study was carried out in a specific range of temperature and time of exposure, however, it adds to previous studies findings, and together may be useful to assess the reliability of dental DNA typing for human identification.

Received: 6 July 2020; Accepted: 26 May 2021

Published online: 09 June 2021

\section{References}

1. Budimlija, Z. M. et al. World Trade Center human identification project: Experiences with individual body identification cases. Croat. Med. J. 44, 259-263 (2003).

2. Alonso, A. et al. Challenges of DNA profiling in mass disaster investigations. Croat. Med. J. 46, 540-548 (2005).

3. Sudoyo, H. et al. DNA analysis in perpetrator identification of terrorism-related disaster: Suicide bombing of the Australian Embassy in Jakarta 2004. Forensic Sci. Int. Genet. 2, 231-237 (2008).

4. Fanton, L., Jdeed, K., Tilhet-Coartet, S. \& Malicier, D. Criminal burning. Forensic Sci. Int. 158, 87-93 (2006).

5. Schwark, T., Heinrich, A., Preuße-Prange, A. \& Von Wurmb-Schwark, N. Reliable genetic identification of burnt human remains. Forensic Sci. Int. Genet. 5, 393-399 (2011).

6. Ubelaker, D. H. The forensic evaluation of burned skeletal remains: A synthesis. Forensic Sci. Int. 183, 1-5 (2009).

7. Harbeck, M. et al. Research potential and limitations of trace analyses of cremated remains. Forensic Sci. Int. 204, 191-200 (2011).

8. Rubio, L., Sioli, J. M., Suarez, J., Gaitan, M. J. \& Martin-de-las-Heras, S. Spectrophotometric analysis of color changes in teeth incinerated at increasing temperatures. Forensic Sci. Int. 252(193), e1-193.e6. https://doi.org/10.1016/j.forsciint.2015.04.033 (2015). 
9. Garriga, J. A., Ubelaker, D. H. \& Zapico, S. C. Evaluation of macroscopic changes and the efficiency of DNA profiling from burnt teeth. Sci. Justice 56, 437-442 (2016).

10. Godinho, R. M. et al. Is enamel the only reliable hard tissue for sex metric estimation of burned skeletal remains in biological anthropology?. J. Archaeol. Sci. Rep. 26, 101876. https://doi.org/10.1016/j.jasrep.2019.101876 (2019).

11. Malaver, P. \& Yunis, J. Different dental tissues as source of DNA for human identification in forensic cases. Croat. Med. J. 44, 306-309 (2003).

12. Maciejewska, A., Wlodarczyk, R. \& Pawlowski, R. The influence of high temperature on the possibility of DNA typing in various human tissues. Folia Histochem. Cytobiol. 53, 322-332 (2015).

13. Sweet, D. J. \& Sweet, C. H. DNA analysis of dental pulp to link incinerated remains of homicide victim to crime scene. J. Forensic Sci. 40, 310-314 (1995).

14. Yamada, Y. et al. Sequencing mitochondrial DNA from a tooth and application to forensic odontology. J. Forensic Odontostomatol. 15, 13-16 (1997).

15. Rubio, L., Sioli, J. M., Gaitán, M. J. \& Martin-de-Las-Heras, S. Dental color measurement to predict DNA concentration in incinerated teeth for human identification. PLoS One 13(4), e0196305. https://doi.org/10.1371/journal.pone.0196305 (2018).

16. Remualdo, V. R. Avaliação de três métodos de extração de DNA de dentes humanos submetidos ao calor (Universidade de São Paulo, 2004).

17. Dobberstein, R. C., Huppertz, J., von Wurmb-Schwark, N. \& Ritz-Timme, S. Degradation of biomolecules in artificially and naturally aged teeth: Implications for age estimation based on aspartic acid racemization and DNA analysis. Forensic Sci. Int. 179, 181-191 (2008).

18. Federchook, T., Pokines, J., Crowley, K. \& Grgicak, C. Recovery of DNA from teeth exposed to variable temperatures. Forensic Anthropol. 2, 143-151 (2019).

19. Devaraju, D. et al. DNA detection in tooth exposed to different temperatures: An in vitro study. J. Indian Acad. Oral Med. Radiol. 26, 393. https://doi.org/10.4103/0972-1363.155681 (2014).

20. Tsuchimochi, T. et al. Chelating resin-based extraction of DNA from dental pulp and sex determination from incinerated teeth with Y-chromosomal alphoid repeat and short tandem repeats. Am. J. Forensic Med. Pathol. 23, 268-271 (2002).

21. Lee, S. B., Mccord, B. \& Buel, E. Advances in forensic DNA quantification: A review. Electrophoresis 35, 3044-3052 (2014).

22. Rubio, L., Santos, I., Gaitan, M. J. \& Martin de-las Heras, S. Time-dependent changes in DNA stability in decomposing teeth over 18 months. Acta Odontol. Scand. 71, 638-643 (2013).

23. Kemp, B. M. \& Smith, D. G. Use of bleach to eliminate contaminating DNA from the surface of bones and teeth. Forensic Sci. Int. 154, 53-61. https://doi.org/10.1016/j.forsciint.2004.11.017 (2005).

24. Adler, C. J., Haak, W., Donlon, D. \& Cooper, A. Survival and recovery of DNA from ancient teeth and bones. J. Archaeol. Sci. 38, 956-964. https://doi.org/10.1016/j.jas.2010.11.010 (2011).

25. Pajnič, I. Z., Pogorelc, B. G., Balažic, J., Zupanc, T. \& Štefanič, B. Highly efficient nuclear DNA typing of the World War ii skeletal remains using three new autosomal short tandem repeat amplification kits with the extended European Standard Set of loci. Croat. Med. J. 53, 17-23. https://doi.org/10.3325/cmj.2012.53.17 (2012).

26. Koehn, K., Buettner, A. \& Lindner, I. Effect of sodium hypochlorite decontamination on the DNA recovery from human teeth. Int. J. Legal Med. 134, 93-99. https://doi.org/10.1007/s00414-019-02174-2 (2020).

27. Alvarez-Garcia, A. et al. Effect of environmental factors on PCR-DNA and from dental pulp. Int. J. Legal Med. 109, 125-129 (1996).

28. Quantifiler Kits, User's Manual (Applied Biosystems, 2006).

29. Qubit dsDNA BR Assay Kits, User Guide (Thermo Fisher Scientific, 2015).

30. Qubit dsDNA HS Assay Kits, User Guide (Thermo Ficher Scientific, 2015).

31. I. Agilent Technologies, Agilent 2100 Bioanalyzer 2100 Expert User's Guide, Waldbronn, 2006. papers2://publication/ uuid/49077082-F79D-4B5C-97A7-83C46842CE1A.

32. I. Agilent Technologies, Agilent High Sensitivity DNA Kit Guide, Waldbronn, 2013. https://www.agilent.com/cs/library/userm anuals/Public/G2938-90321_SensitivityDNA_KG_EN.pdf.

33. AmpFlSTR Identifiler PCR Amplification Kit. User's Manual (Applied Biosystems, 2006).

34. Tvedebrink, T., Eriksen, P. S., Mogensen, H. S. \& Morling, N. Statistical model for degraded DNA samples and adjusted probabilities for allelic drop-out. Forensic Sci. Int. Genet. 6, 97-101 (2012).

35. Rubio, L., Martinez, L. J., Martinez, E. \& De Las Heras, S. M. Study of short- and long-term storage of teeth and its influence on DNA. J. Forensic Sci. 54, 1411-1413 (2009).

36. Tvedebrink, T., Mogensen, H. S., Stene, M. C. \& Morling, N. Performance of two 17 locus forensic identification STR kits-Applied Biosystems's AmpFeSTR NGMSElect and Promega's PowerPlex ESI17 kits. Forensic Sci. Int. Genet. 6, 523-531 (2012).

37. Bright, J. A., Taylor, D., Curran, J. M. \& Buckleton, J. S. Degradation of forensic DNA profiles. Aust. J. Forensic Sci. 45, 445-449 (2013).

38. R Core Team. R: A language and environment for statistical computing (R Found. Stat. Comput., 2014). https://www.r-project.org/.

39. Kremser, A., Bayer, B., Jung, S. \& Anslinger, K. Quantifiler Human DNA Quantification Kit (Applied Biosystems) as a screening kit for DNA profiling. Forensic Sci. Int. Genet. Suppl. Ser. 2, 106-107 (2009).

40. Urbani, C., Lastrucci, R. D. \& Kramer, B. The effect of temperature on sex determination using DNA-PCR analysis of dental pulp. J Forensic Odontostomatol. 17, 35-39 (1999).

41. Zapico, S. C. \& Ubelaker, D. H. Sex determination from dentin and pulp in a medicolegal context. J. Am. Dent. Assoc. 144, 1379-1385. https://doi.org/10.14219/jada.archive.2013.0074 (2013).

42. Sedlackova, T., Repiska, G., Celec, P., Szemes, T. \& Minarik, G. Fragmentation of DNA affects the accuracy of the DNA quantitation by the commonly used methods. Biol. Proced. Online 15, 5 (2013).

43. Georgiou, C. D. \& Papapostolou, I. Assay for the quantification of intact/fragmented genomic DNA. Anal. Biochem. 358, 247-256 (2006).

44. Kline, M. C., Duewer, D. L., Redman, J. W. \& Butler, J. M. Results from the NIST 2004 Quantitation Study. J. Forensic Sci. 50, 571-578 (2005).

45. Green, R. L., Roinestad, I. C., Boland, C. \& Hennessy, L. K. Developmental validation of the Quantifiler Real-Time PCR Kits for the quantification of human nuclear DNA samples. J. Forensic Sci. 50, 809-825 (2005).

46. Shokere, L. A., Holden, M. J. \& Ronald Jenkins, G. Comparison of fluorometric and spectrophotometric DNA quantification for real-time quantitative PCR of degraded DNA. Food Control 20, 391-401 (2009).

47. Timken, M. D., Klein, S. B. \& Buoncristiani, M. R. Stochastic sampling effects in STR typing: Implications for analysis and interpretation. Forensic Sci. Int. Genet. 11, 195-204 (2014).

48. Butler, J. M. STR genotyping and data interpretation, in Fundam. Forensic DNA Typing, 205-227 (Academic Press-Elsevier, 2009).

49. Lindahl, T. \& Nyberg, B. Heat-induced deamination of cytosine residues in deoxyribonucleic acid. Biochemistry 13, 3405-3410. https://doi.org/10.1021/bi00713a035 (1974).

50. Ehrlich, M., Norris, K. F., Wang, R. Y., Kuo, K. C. \& Gehrke, C. W. DNA cytosine methylation and heat-induced deamination. Biosci. Rep. 6, 387-393. https://doi.org/10.1007/BF01116426 (1986).

51. Gorden, E. M., Sturk-Andreaggi, K. \& Marshall, C. Repair of DNA damage caused by cytosine deamination in mitochondrial DNA of forensic case samples. Forensic Sci. Int. Genet. 34, 257-264. https://doi.org/10.1016/j.fsigen.2018.02.015 (2018).

52. Karni, M., Zidon, D., Polak, P., Zalevsky, Z. \& Shefi, O. Thermal degradation of DNA. DNA Cell Biol. 32, 298-301 (2013). 
53. Booth, C. S. et al. Efficiency of the polymerase chain reaction. Chem. Eng. Sci. 65, 4996-5006 (2010).

54. Mattayat, D., Kitpipit, T., Phetpeng, S., Asawuangkul, W. \& Thanakiatkrai, P. Comparative performance of AmpFLSTR Identifiler Plus PCR Amplification Kit and QIAGEN Investigator IDplex Plus Kit. Sci. Justice 56, 468-474 (2016).

55. Debernardi, A. et al. One-year variability of peak heights, heterozygous balance and inter-locus balance for the DNA positive control of AmpFeSTR Identifiler STR Kit. Forensic Sci. Int. Genet. 5, 43-49 (2011).

\section{Author contributions}

L.R. and S.M.H. conceived the project, developed the dataset, oversaw data collection and reviewed the original draft. D.L.P. and M.J.G. refined the data set, analyzed the data and produced the first draft of the report. D.L.P. and L.R. wrote the original draft. I.S. and E.V. oversaw the project and interpreted the data. All authors reviewed and approved the manuscript.

\section{Funding}

This research was funded by the University of Malaga (PPIT.UMA.B1.2020/20).

\section{Competing interests}

The authors declare no competing interests.

\section{Additional information}

Supplementary Information The online version contains supplementary material available at https://doi.org/ 10.1038/s41598-021-91505-8.

Correspondence and requests for materials should be addressed to L.R.

Reprints and permissions information is available at www.nature.com/reprints.

Publisher's note Springer Nature remains neutral with regard to jurisdictional claims in published maps and institutional affiliations.

(c) (i) Open Access This article is licensed under a Creative Commons Attribution 4.0 International License, which permits use, sharing, adaptation, distribution and reproduction in any medium or format, as long as you give appropriate credit to the original author(s) and the source, provide a link to the Creative Commons licence, and indicate if changes were made. The images or other third party material in this article are included in the article's Creative Commons licence, unless indicated otherwise in a credit line to the material. If material is not included in the article's Creative Commons licence and your intended use is not permitted by statutory regulation or exceeds the permitted use, you will need to obtain permission directly from the copyright holder. To view a copy of this licence, visit http://creativecommons.org/licenses/by/4.0/.

(C) The Author(s) 2021 